\title{
Growth and lipid profiles of the Antarctic snow microalga Chlamydomonas sp. in response to changes in temperature, photoperiod, salinity and substrate
}

\author{
Perfiles de lípidos y crecimiento de la microalga antártica Chlamydomonas sp. \\ en respuesta a los cambios de temperatura, fotoperiodo, salinidad y sustrato
}

Pedro Cid-Agüero ${ }^{1}$, Joel L. Cuello ${ }^{2}$, Sebastian Ruiz ${ }^{3,4}$, Gloria Sanchez ${ }^{1}$

\section{Resumen}

El principal objetivo de este estudio fue investigar la variación de lípidos totales en relación a la adaptación al frío, sustratos de cultivo y condiciones de estrés, intentando homologar la adaptación ambiental a corto plazo de microalgas antárticas fotosintéticas. Cultivos de la microalga de nieve antártica Chlamydomonas sp. (cepa DPA-02) fueron obtenidos después de dos años de almacenamiento a $-4^{\circ} \mathrm{C}$ y sin fuente de luz. Chlamydomonas sp. (DPA-02) exhibió alta fotosensibilidad, creciendo óptimamente en medio Bristol bajo un nivel de luz de $10 \mu \mathrm{mol} \mathrm{m} \mathrm{m}^{-2} \mathrm{~s}^{-1} \mathrm{y}$ una temperatura de $12 \pm 2^{\circ} \mathrm{C}$.

Las microalgas de las nieves produjeron el $93 \%$ de su contenido de lípidos como ácidos grasos saturados, el $67 \%$ de los cuales era ácido palmítico (C16:0). El estudio también mostró la alteración significativa del perfil lipídico de la microalga al modificar las condiciones de crecimiento del cultivo, resultando en un aumento significativo de PUFAs independientemente de la temperatura del cultivo, este incremento fue desde un $10 \%$ a un $70 \%$ aproximadamente cuando el cultivo fue sometido a oscuridad continua durante un período de tiempo de un mes. Adicionalmente, la tasa de crecimiento de la microalga disminuyó con el aumento de la concentración de $\mathrm{NaCl}$ en el medio de cultivo. Igualmente, se encontró que la microalga era sensible a la matriz física en la que crecía, mostrando una mayor tasa de mortalidad cuando se exponía a un shock de baja temperatura en un medio sólido distinto de la nieve o el hielo. Estos resultados proporcionan nuevos antecedentes sobre las estrategias crioprotectoras empleadas por microalgas de nieve para sobrevivir bajo las severas condiciones ambientales de la Antártida.

\section{Palabras Clave:}

microalgas de nieve; contenido de lípidos; adaptación al frío; crioprotector; fotoperiodo

\section{Abstract}

The main objective of this study was to investigate culture substrates, stress conditions and coldadaptive cellular lipid products of potential industrial interest associated with the short-term environmental adaptation by an Antarctic snow microalga. Viable culture lines of the Antarctic snow microalga Chlamydomonas sp. (DPA-02 strain) were obtained after two years storage period at $-4{ }^{\circ} \mathrm{C}$ without light source. The darkadapted Chlamydomonas sp. exhibited high sensitivity to light, growing optimally on Bristol

1 Dirección de Programas Antárticos, Universidad de Magallanes, Av. Bulnes 01855, Punta Arenas, Chile. $\triangle$ pedro.cid@umag.cl; glsanchez@udec.cl

2 Department of Agricultural and Biosystems Engineering, The University of Arizona, U.S.A. cuelloj@email.arizona.edu

3 Magister en Ciencias Antárticas con Mención en Glaciología, Universidad de Magallanes, Punta Arenas, Chile.sruizpp@gmail.com

4 Instituto de Geografía, Pontificia Universidad Católica de Chile, Santiago de Chile. 
media under a light level of $10 \mu \mathrm{mol} \mathrm{m} \mathrm{m}^{-2} \mathrm{~s}^{-1}$ and a temperature of $12 \pm 2^{\circ} \mathrm{C}$. The snow microalga yielded $93 \%$ of its lipid content as saturated fatty acids, $67 \%$ of which was palmitic acid (C16:0). The study also showed the significant alteration of the microalga's lipid profile by modifying the culture's growing conditions, resulting in a significant increase in PUFA's independently of the culture temperature, from about $10 \%$ to $70 \%$, when the culture was subjected to continuous darkness over a one-month period. The growth rate of the microalga decreased with increase in $\mathrm{NaCl}$ concentration in the growing medium. Further, the microalga was found to be sensitive to the physical matrix on which it grew, showing a higher mortality rate when exposed to a low-temperature shock on a solid medium different than snow or ice. These results provided unprecedented insights into cryoprotective strategies employed by snow microalgae to survive under the severe environmental conditions of Antarctica.

\section{Key words:}

snow microalgae; lipids content; cold adaptation; cryoprotectant; photoperiod

\section{INTRODUCTION}

Snow microalgae are a group of freshwater extremophile organisms that represent several psychrophilic (or cold-loving) microalgae and cyanobacteria able to grow on snow and ice during alpine and polar summers (Kawecka, 1978). Their optimum growth temperature is generally around $0^{\circ} \mathrm{C}$ (Teoh et al. 2004). In order to effectively adapt to the harsh environment, snow microalgae have developed a number of adaptive features to maintain growth, reproduction and metabolic activity, which include biosynthesis of pigments (Fong et al. 2001), polyols (Arnold et al. 2003; Leya et al. 2009), sugars (Arnold et al. 2003) and lipids (Pocock et al. 2011; Zang et al. 2003). Their dormant state, which enables them to withstand subzero temperatures in winter, implies the storage of large amounts of reserves in the form of lipids, polyols and sugars (Rezanka et al. 2008). The protective attributes of polyunsaturated fatty acids especially at low temperature help snow algae to survive and adapt to extreme environments (Becker et al. 2010; Guschina et al. 2006) by increasing membrane fluidity, and reducing their metabolism, and avoiding intracellular ice formation (Lyon et al. 2014; Pearce, 2008).

The lipid profile (and cellular cycle) of snow microalgae is sensitive to physical and chemical factors (Piorreck et al. 1984; Guckert \& Cooksey, 1990; Hu et al. 2008). Previous studies have shown that lipid content in some microalgae can be modified by various growth conditions including temperature, light, and media composition (Guckert \& Cooksey, 1990; $\mathrm{Hu}$ et al. 2008) Similar response as a cold adaptation mechanism to these conditions has been described in marine benthic microalgae and seaweed (Gomez et al. 2009). Temperature has been found to have a major effect on the total lipid content in algae. For example, the lipid content of Chrysophyta, Ochromonas Danica (Aaronson, 1973), and the eustigmatophyte, Nannochloropsis salina (Boussiba et al. 1987), increased in direct proportion with temperature. Further, both low light intensity and low nitrogen levels typically induce the formation of polar lipids (Hu et al. 2008).

Numerous studies reported that the occurrence of certain lipid characteristics coincided with the capacity to withstand lowtemperature stress. High proportions of unsaturated fatty acids were observed in red cells of Chlamydomonas nivalis from Antarctica (Bidigare et al. 1993), while unusual short- and medium-chain polyunsaturated fatty acids were isolated from the flagellated cells of the snow alga Chloromonas brevispina (Rezanka et al. 2008). However, these reports were based on single measurements of field samples. Only limited evidence documents the variability in fatty acid content of different strains under varying controlled conditions in the laboratory (Spijkerman et al. 2012). Thermal fluctuations instantaneously influence rates of photosynthetic electron transfer, while longer exposure to supra- or super-optimal temperatures causes reversible or permanent changes in rates of synthesis and degradation of both primary and secondary metabolites. The effects of short 
acclimation to a wide span of temperatures on photosynthetic electron transfer, lipid and fatty acid composition in the snow alga have been measured on Chlamydomonas cf. nivalis (Lukes et al. 2014), Further, the response to a combination of stressors such as high ultra violet (UV) radiation and enhanced temperatures has been recently measured for marine Antarctic and sub-Antarctic microalgae (Cruces et al. 2012) as well as for other marine organisms (Gunderson et al. 2016).

Green snow microalgae populations present in the Northern Antarctic Peninsula are subject to continuous freeze-thaw cycles during the warm season. In winter, these populations are buried under the snowpack, possibly entering a metabolically dormant state sufficiently adapted to endure a "seasonally" scarce environment. Implicit in their name, snow algae's substrate is snow, and snowpacks usually have an active hydrology, potentially locating microalgae populations in a soil-snow interphase at certain times. Viable microalgae populations have indeed been extracted from permafrost samples (Vishnivetskaya et al. 2007), raising the question of whether algae viability can be maintained on different physical substrates.

Snow algae are exposed to a large variety of environmental conditions. For instance, incoming sea aerosols alter the salinity of warm season's remnant snow cover, changing the immediate environment of the cells. In the case of polycrystalline ice, it contains a chemically concentrated liquid phase creating an interconnected network of veins which may provide a proper liquid environment and nutrients for microorganisms to survive (Mader, 1992; Mader et al. 2006). Avoidance of cryoinjury as side-effect of crystal growth will depend on the balance between processes such as diffusion rates (Rapatz et al. 1966) and the presence of solutes in the surrounding environment, matrix in terms of continuous space.

It is the metabolically-mediated ability of snow algae to survive and adapt to low temperatures that served as the basis for our hypothesis that snow microalgae generate cellular products to aid their enhanced cold adaptation, including lipids and unsaturated fatty acids with higher fluidity at freezing temperatures. The aim of the present study was to investigate the main cryoprotective molecules involved in the cold-adaptation of the snow microalgae Chlamydomonas sp. (DPA-02 strain).

\section{MATERIALS AND METHODS}

\section{a) Sample}

Samples of freshwater green snow microalgae, belonging to the family Chlamydomonadaceae, were collected near the Chilean Antarctic Base General Bernardo O'Higgins (63 $19^{\prime}$ S - 57 54' $\mathrm{W}$ ) in Antarctica (Fig 1). This site is characterized by an average minimum temperature of approximately $-12^{\circ} \mathrm{C}$, strong winds and high relative levels of marine aerosols due to the Western winds in the Antarctic Peninsula (Aristarain et al. 2002). The microalgae samples were collected on January 2011 from a snow surface which had a temperature of approximately $-1^{\circ} \mathrm{C}$ and a $\mathrm{pH}$ of 7.8 . The snow microalgae samples were then stored at $-4^{\circ} \mathrm{C}$ and kept frozen in the dark continuously for a period of two years. The snow microalga used in the present study was subsequently identified at Universidad de Magallanes (UMAG) collection as Chlamydomonas sp. (DPA-02 strain).

\section{b) Algal culture}

The growth of microalgae varied in accordance with culture conditions; thus, growth was investigated relative to various factors, including light, temperature and culture medium media. The microalgae cultures were maintained in a controlledenvironment room at temperatures ranging from 4 to $20^{\circ} \mathrm{C}$, illuminated with cool white fluorescent lamps at light levels from 2 to $250 \mu \mathrm{mol} \mathrm{m} \mathrm{m}^{-2} \mathrm{~s}^{-1}$ and at 12:12 h light-dark cycles. An AEMC model CA811 quantum light sensor with meter was used to measure the photosynthetically active radiation (PAR) incident on the cultures. Green microalgae cultures were grown in Erlenmeyer flasks using different types of liquid media, including modified Chu-13, F/2 and Bristol, at different temperature levels, with each temperature treatment having triplicates of samples. 

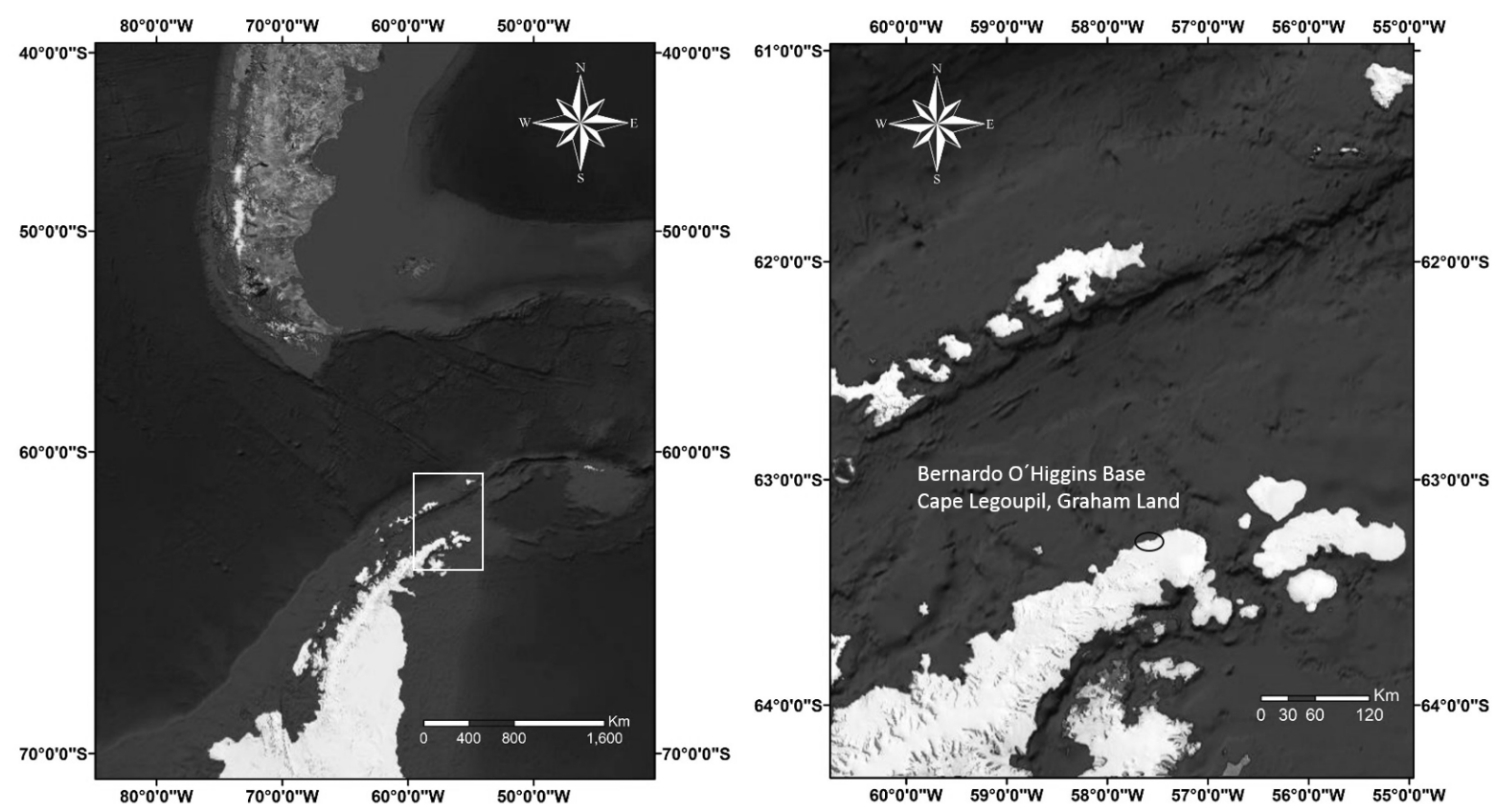

Fig. 1. Maps showing the location of the Antarctic Peninsula (left) and the Chilean Base Gral. Bernardo O'Higgins (63 19 'S, 57 54' W) (right). [Adapted from Aristarain et al. 2002]

Growing the microalgae cultures at low light levels eventually led to their successful cultivation in liquid medium after two years of being stored in a freezer in continuous darkness. The microalgae growth was found to be highest in Bristol medium at a photosynthetic photon flux $(\mathrm{PPF})$ of $5.83 \pm 0.49 \mu \mathrm{mol}$ photon $\mathrm{m}^{-2} \mathrm{~s}^{-1}$. After four days at $12^{\circ} \mathrm{C}$, the microalgal cell count, conducted using a Neubauer's camera, increased from 26,000 cells $/ \mathrm{mL}$ to 400,000 cells $/ \mathrm{mL}$. These samples were replicated in fresh media with 1:2 and 1:4 dilutions and incubated for four days. The cultures were grown at temperature levels of $12 \pm 2^{\circ} \mathrm{C}$ and $24 \pm 2^{\circ} \mathrm{C}$, and at light levels of 10 and $200 \mu \mathrm{mol} \mathrm{m} \mathrm{m}^{-2} \mathrm{~s}^{-1}$.

A qualitative evaluation of the results showed that the cultures grew appreciably better at the lower temperature of $12 \pm 2^{\circ} \mathrm{C}$ and at the lower light level of about $10 \mu \mathrm{mol} \mathrm{m} \mathrm{s}^{-1}$, regardless of the growth medium used. These results were consistent with our previous results when working with fresh microalgae samples (Cid-Agüero et al. 2012).

A follow-up experiment was conducted where the cultures were grown at a temperature of $12 \pm 2^{\circ} \mathrm{C}$, at a light intensity of $5.8 \mu \mathrm{mol}$ photon $\mathrm{m}^{-2} \mathrm{~s}^{-1}$, at approximately $0.1 \mathrm{vvm}$ of constant aeration and using both $\mathrm{F} / 2$ and Bristol media. In both culture media, an initial decrease in cell concentration and an adaptation period of about six days were observed, after which the cultures began their exponential phase of growth. Higher growth was observed in the Bristol medium with the cell count averaging at $2.6 \times 10^{6}$ cells $/ \mathrm{mL}$ during the exponential phase.

\section{c) Algal lipid content}

Flow cytometric analysis of polar and neutral membrane lipids was performed at the BioRen UFRO, Temuco. Samples of green snow microalgae were analyzed. Nile-Red lipophilic stain dye protocol was performed for preparing samples prior to cytometry. Excitation and emission wavelengths were set at 485 and 525 $\mathrm{nm}$, respectively. No quantitative normalization was performed per cell unit, but auto-fluorescence was corrected.

An original lyophilized sample of green microalgae was submitted to a specialized company, Desert Bioenergy SA, for total lipids and Fatty acid analysis.

To evaluate the importance of the seasonal photoperiods in the fatty acids (FA) production 
and quality among Antarctic snow microalgae, samples of Chlamydomonas sp. (DPA-02 strain), which had been growing at approximately 10 umol photon $\mathrm{m}^{-2} \mathrm{~s}^{-1}$, were exposed to darkness for a one-month period at different temperature treatments of $0^{\circ} \mathrm{C}, 4^{\circ} \mathrm{C}, 13^{\circ} \mathrm{C}, 18^{\circ} \mathrm{C}$ and $23^{\circ} \mathrm{C}$. The samples were submitted to a specialized Laboratory (MicrobialID ${ }^{\circledR}$ ) that analyzed the samples by using Q-FAME technique. Fatty acids were separated from each microalga, converted to fatty acid methyl esters (FAMEs) and analyzed by Gas Chromatography (GC) for lipids profile. The control used for the experiment was a sample of the microalga which was grown in fed-batch culture at $13{ }^{\circ} \mathrm{C}$ under a light level of approximately $10 \mu \mathrm{mol}$ photon $\mathrm{m}^{-2} \mathrm{~s}^{-1}$. Each week, a volume of Bristol medium equivalent to $12.5 \%$ of batch volume was added. After one month, the profile of the elementary FA composition was analyzed.

\section{d) Salinity}

Growth of the snow microalga Chlamydomona sp. (DPA-02 strain) was evaluated under five conditions of salinity: 0, 4, 8, 11 and 16 Practical Salinity Unit (PSU), by adding $\mathrm{NaCl}$ (sodium chloride 99.99 Suprapur ${ }^{\circledR}$ ) to the Bristol culture medium. The PSU scale defines salinity in terms of the conductivity ratio of a sample to that of a solution of $32.4356 \mathrm{~g}$ of $\mathrm{KCl}$ at $15^{\circ} \mathrm{C}$ in a $1 \mathrm{~kg}$ solution. Each treatment was performed in triplicates. Assays were performed with continuous light photoperiod at an average light intensity of $5.8 \mu \mathrm{mol}$ photon $\mathrm{m}^{2} \mathrm{~s}^{-1}$, and a temperature of $12 \pm 2^{\circ} \mathrm{C}$, at constant aeration. All trials allowed for a period of acclimation to the culture conditions; however, the treatment with high salinity (16 UPS) never exceeded the initial stocking density.

\section{e) Cryo-injury}

Cell viability after extreme cold exposure and potential cytotoxic effect of sediment upon freezing was evaluated. The cell survival/ mortality was tested by two methods: (1) the exclusion dye Trypan Blue ${ }^{\circledR}$ was used to determine accumulated mortality in each condition; and (2) the colorimetric assay for assessing cytotoxicity. CellTiter $96^{\circledR}$ Aqueous One Solution Cell Proliferation Assay (MTS), was used to determine cytotoxicity and cell viability as indirect method on the basis that viable cells produce a measurable product in higher magnitude than damaged cells (Capasso et al. 2003). The MTS tetrazolium compound was bioreduced by cells into a colored soluble formazan product. This conversion was accomplished by NADPH/NADH produced by dehydrogenase enzymes in metabolically active cells.

Viability of Chlamydomonas sp. (DPA-02 strain) cultures at 4,2 and 1.3 million cells $/ \mathrm{mL}$ after being cooled down to $-36^{\circ} \mathrm{C}$ at a rate of $0.5^{\circ} \mathrm{C} / \mathrm{min}$ was compared to no-freezing $\left(4^{\circ} \mathrm{C}\right)$ control plates. Both sets accounted for different particle size fractions obtained from sandyloam sediment with an approximate wetness coefficient of $24 \%$. This sediment was considered equivalent to that under the snowpack at the microorganism's habitat.

The protocol utilized cell culture at $4,000,000$ cells $/ \mathrm{mL}$ and the corresponding membrane-filtered sediment fractions of sand, clay and silt present in $10 \mathrm{~mL}$. Final fractions were dried, weighed, sterilized (dry-heat, $\sim 170^{\circ} \mathrm{C}$ for 2 hours) and divided $1 / 20$ to match the final assay volume with $500 \mu \mathrm{L}$ of cell culture in Bristol medium. The sets of plates were restricted from light intensity for 24 hours before the assay. A recovery window at $10^{\circ} \mathrm{C}$ for 12 hours with light restriction was advised for both conditions prior to perform the Trypan cell counting and MTS reaction. Plates were allowed $1.5 \mathrm{~h}$ at $23^{\circ} \mathrm{C}$ for reaction. Each well was then centrifuged at $13,000 \mathrm{rpm}$ (avoiding interference of particles in suspension) and absorbance was read at 490nm.

A Kolgomorov-Smirnov Test rejected the null hypothesis that data came from standard normal distribution at $5 \%$ significance ( $p$-value = $3.42 e-10)$, indicating that the data did not come from a continuous normal distribution. Also, Sand and Silt assays rendered a Kruskal-Wallis Test $p$ Chi-Sq. value <0.05 (Prob. Chi-sq = 0.0187); hence, representing pairs with uneven means. Other control-variable pairs, Particle-control and Clay, resulted in non rejectable hypothesis of uneven means by the same Test. 


\section{RESULTS}

\section{a) Fatty Acid Profiles}

The total lipid composition of the green Antarctic snow microalga Chlamydomonas sp. (DPA-02 strain), analyzed by flow cytometry, was found to be $93 \%$ neutral lipids and $7 \%$ polar lipids. Lyophilized samples of the snow microalga showed a lipid content of $0.96 \%$ based on dry biomass. These results are summarized in Table 1.

GC-FID chromatography determined a fatty acid profile that included: palmitic acid, C16:0 (37\%); oleic acid, C18:1 n9c (24\%); stearic acid, C18:0 (21\%); and elaidic acid, C18:1 n9c (14\%), as shown in Table 2. The lipid profile of the initial sample for experiments was found to be about $58 \%$ SAFAs, $40 \%$ MUFAs, and 2\% PUFAs. b) Fatty acid profile response to dark period

The control samples of Chlamydomonas sp. (DPA-02 strain) grown under the light at approximately $10 \mu \mathrm{mol}$ photon $\mathrm{m}^{-2} \mathrm{~s}^{-1}$ showed a high content of SAFAs (63\%) and about $27 \%$ MUFAs and 2\% PUFAs. The snow microalga treatments, however, that were exposed to darkness for a one-month period exhibited fatty acid profiles that were significantly altered, with the SAFA's and MUFA's declining significantly to about $25 \%$ and less than $12 \%$, respectively, and the PUFA's increasing significantly to $58 \%$ to $70 \%$ relative to the control. The foregoing results held true independently of the temperature treatments. The results are summarized in Fig. 2.

Table 1. Total and Saponifiable Lipids for Chlamydomonas sp. (DPA-02 strain) microalgae. Cultures were grown at a temperature of $12 \pm 2^{\circ} \mathrm{C}$, light intensity of $5.8 \mu \mathrm{mol}$ photon $\mathrm{m}^{-2} \mathrm{~s}^{-1}$, constant aeration of $0.1 \mathrm{vvm}$ and using Bristol media. Error represents standard deviation for three dry samples.

\begin{tabular}{ccc}
\hline Parameter & Method & Percent (\%) of dry biomass \\
\hline Total lipids & Bligh and Dyer & $0.96 \pm 0.25$ \\
\hline $\begin{array}{c}\text { Saponifiable (polar lipid) } \\
\text { based on total lipid content }\end{array}$ & GC-FID Chromatography & $11.28 \pm 2.18$ \\
\hline
\end{tabular}

Table 2. Fatty Acid Profile for Chlamydomonas sp. (DPA-02 strain) microalgae (standard

$\mathrm{C} 17$, analysis in triplicate). Cultures were grown at a temperature of $12 \pm 2{ }^{\circ} \mathrm{C}$, light intensity of $5.8 \mu \mathrm{mol}$ photon $\mathrm{m}^{-2} \mathrm{~s}^{-1}$, constant aeration of $0.1 \mathrm{vvm}$ and using Bristol media. Error represents standard deviation for three runs.

\begin{tabular}{ccc}
\hline Formula & Identification (Acid Methyl Ester) & Relative Abundance (\%) \\
\hline C14:0 & myristic & $0.49 \pm 0.60$ \\
C16:1 & methylpalmitoleate & $1.53 \pm 0.54$ \\
C16:0 & Palmitic & $36.67 \pm 6.52$ \\
C18:2 n6c & linoleic & $2.42 \pm 2.12$ \\
C18:1 n9c & oleic & $24.10 \pm 5.63$ \\
C18:1 n9c & elaidic & $14.28 \pm 3.64$ \\
C18:0 & stearic & $21.06 \pm 5.61$ \\
\hline
\end{tabular}




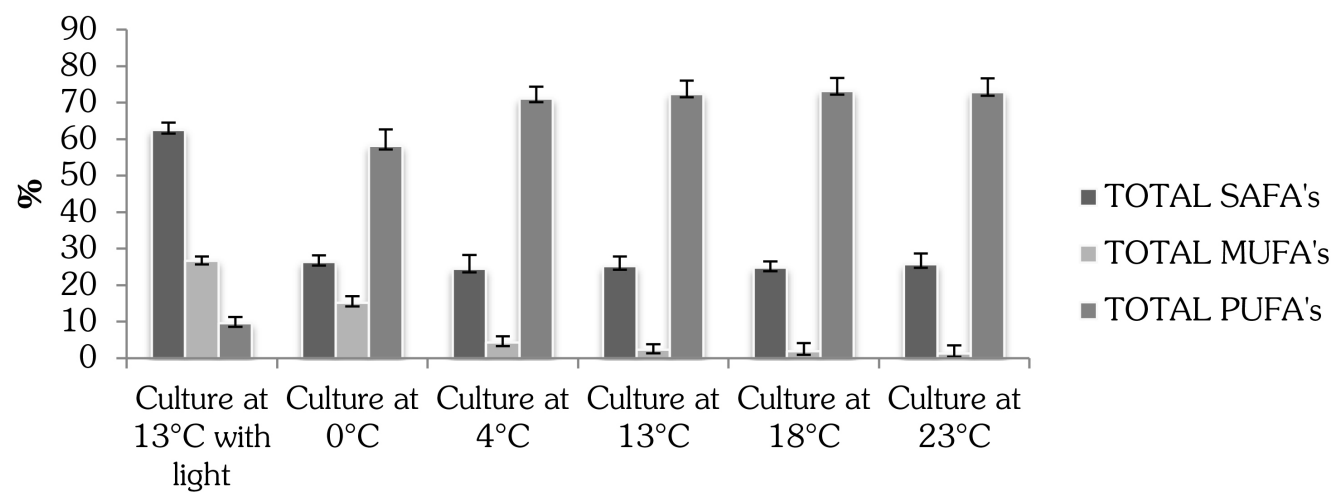

Fig. 2. Relative ratios of total SAFAs, MUFAs, and PUFAs showed by cultures growth in the dark for one month at different temperatures when compared to the fatty acid content of the initial sample.

Error bar represents standard deviation for three runs.

c) Culture response to salinity

The cell culture at 0 UPS exhibited the highest growth rate, followed by the culture at 4 UPS (Fig. 3). During the exponential phase the cultures at 0 UPS and 4 UPS peaked at $2.6 \times 10^{8}$ and $4.5 \times 10^{7}$ cells $/ \mathrm{mL}$, respectively, after 20 days of culture. The cell densities at 0 UPS and

4 UPS increased by two and one order of magnitude, respectively, relative to the initial densities. Cell proliferation was observed in all salinity treatments, except in the treatment for 16 UPS, in which the cell density decreased to $2.2 \times 10^{6} \mathrm{cell} / \mathrm{mL}$.

d) Substrate-induced cryo-injury assay

Exclusion dye Trypan Blue(R) visually distinguished viable from dead cells by staining the

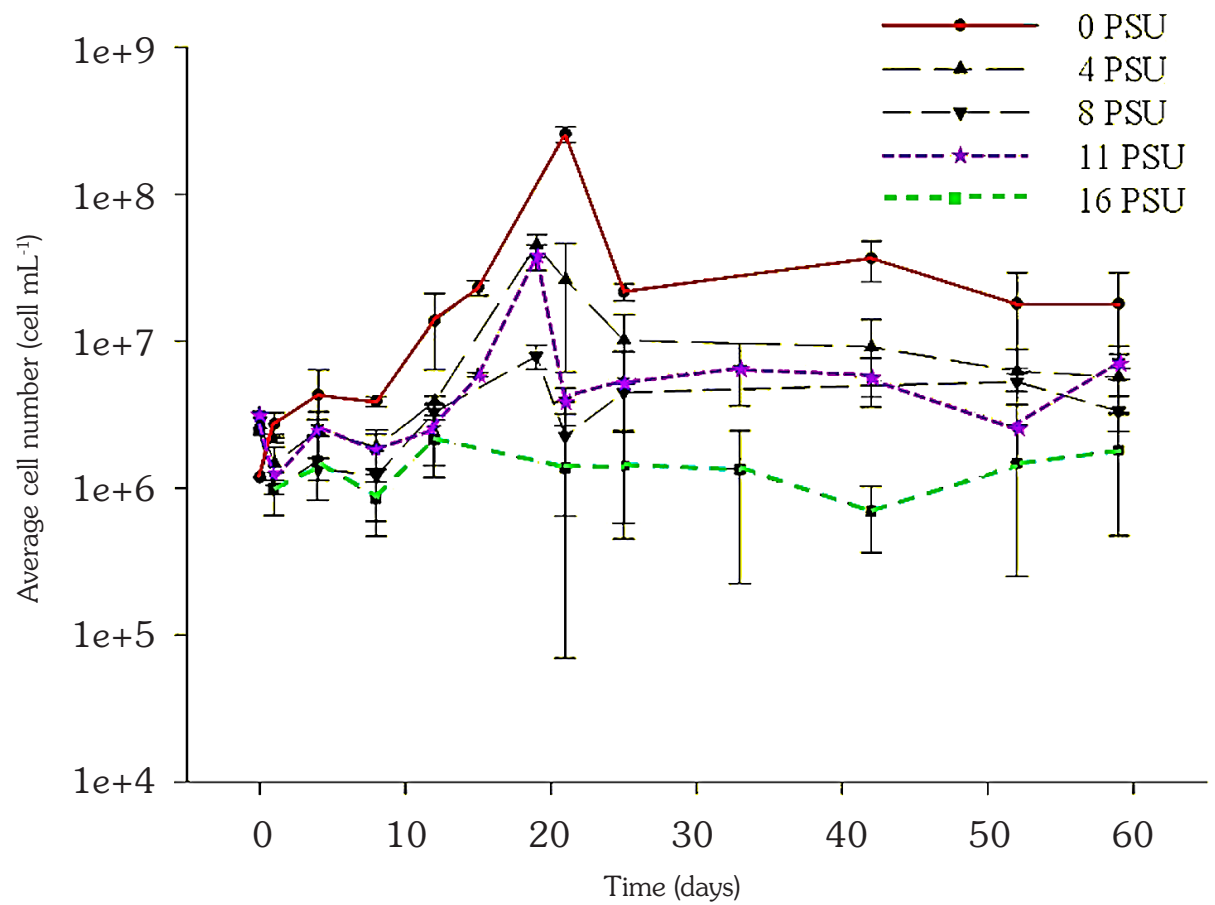

Fig. 3. Cell counting over time in a series of saline concentrations. Cultures were grown at a temperature of $12 \pm 2{ }^{\circ} \mathrm{C}$, light intensity of $5.8 \mu \mathrm{mol}$ photon $\mathrm{m}^{-2} \mathrm{~s}^{-1}$, constant aeration of $0.1 \mathrm{vvm}$ and using Bristol media. Error bar represents standard deviation for three culture samples. 
latter. Sand-particle-containing wells had sevenfold and three-fold mortalities at $-36^{\circ} \mathrm{C}$ and $4{ }^{\circ} \mathrm{C}$, respectively, versus controls (Table 3 ). Silt-fraction wells showed no possible cell count and clayparticle wells showed no clear difference between $-36^{\circ} \mathrm{C}$ and $4^{\circ} \mathrm{C}$, both exhibiting approximately similar levels of mortality as the Bristol medium particle-control wells.

Table 3. Exclusion-dye assay. Particles assayed in either freezing or non-freezing condition for mortality counting.

Ratio of mortality over control is shown. Silt condition had no possible cell-counting in all triplicates.

\begin{tabular}{ccc}
\hline & \multicolumn{2}{c}{ Condition } \\
\hline Particle & $-36^{\circ} \mathrm{C}$ & $4^{\circ} \mathrm{C}$ \\
Sand & 7 & 3.44 \\
Clay & 1.19 & 1.34 \\
\hline
\end{tabular}

MTS assay was used to evaluate changes in metabolically active cells in regard to different growing conditions. These results are summarized in Fig. 4.

When only sand or silt-containing treatments were compared, the alternative hypothesis was accepted. Data does not come from a continuous normal distribution; kolgomorov-smirnov test rejects null hypothesis that data comes from standard normal distribution at $5 \%$ significance ( $p$-value $=3.42 e-10$ ). Sand and Silt assays rendered a kruskal-wallis test $p$ Chi-Sq. value $<0.05$ (Prob. Chi-sq $=0.0187$ ), hence representing pairs with uneven means. Other control-variable pairs, Particle-control and Clay, resulted in non rejectable hypothesis of uneven means by the same test.

\section{DISCUSSION}

\section{Fatty Acid Profiles}

After two years of being stored in a freezer at $-4{ }^{\circ} \mathrm{C}$ in continuous darkness, the Antarctic snow microalga Chlamydomonas sp. (DPA-02 strain) was successfully grown in liquid culture at a photosynthetic photon flux (PPF) of $5.8 \mu \mathrm{mol}$ photon $\mathrm{m}^{-2} \mathrm{~s}^{-1}$ and at a temperature of $12{ }^{\circ} \mathrm{C}$. These results demonstrated both, the significant adaptive capacity of the microalga to preserve its viability during a long-term dark storage in a frozen environment, and its ability to successfully keep its cellular integrity with the necessary adjustments for safekeeping of

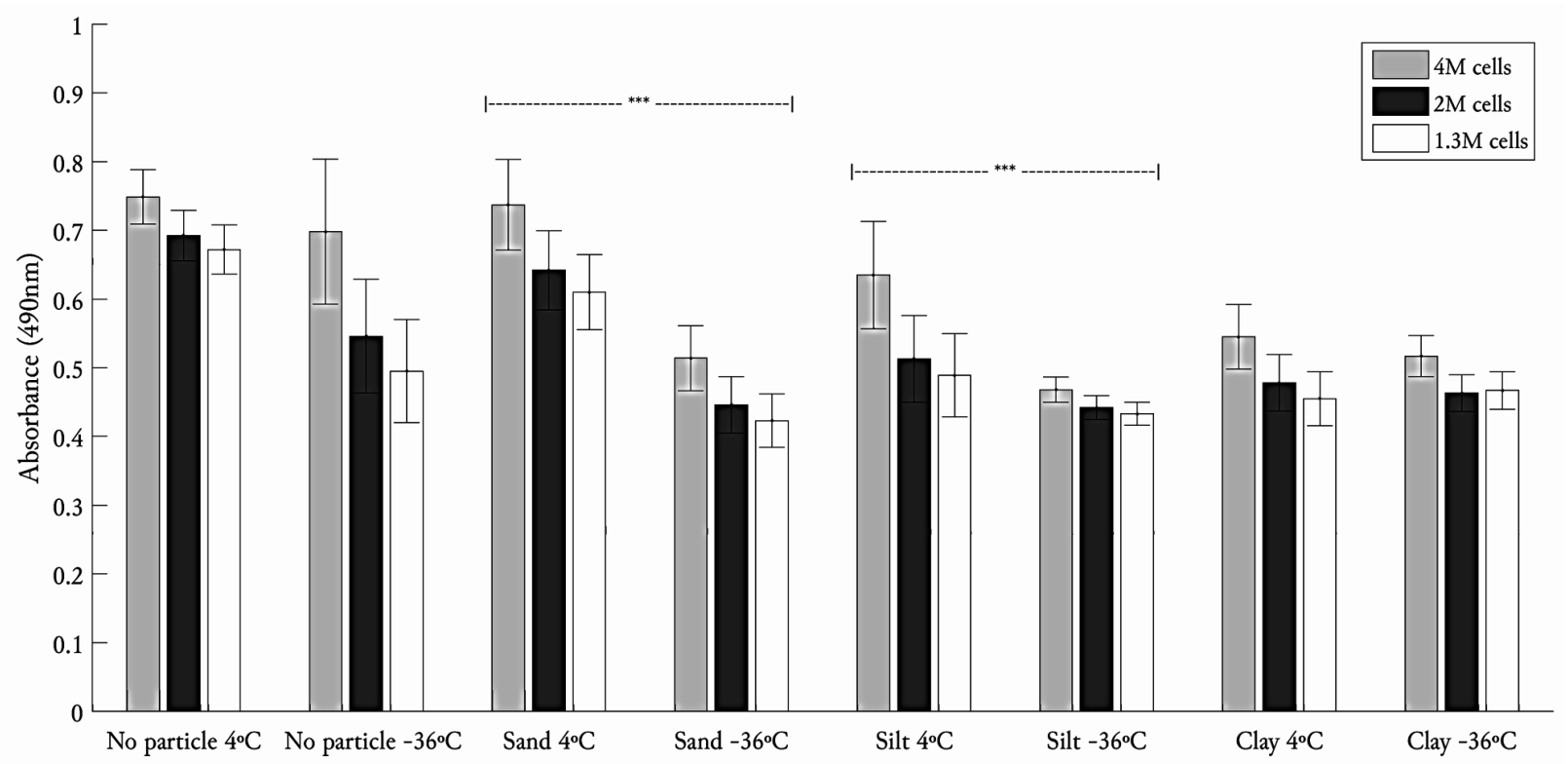

Fig. 4. MTS freezing/particle assays. The assay estimated cryo-injury by reading colorimetric product from metabolically active cells condition. It considered No-particle and No-freezing $\left(4^{\circ} \mathrm{C}\right)$ as controls for each condition. Error bar represents standard deviation. The three asterisks represent the statistically significant $(5 \%)$ mean difference as result of Kruskal-Wallis test $(p<0.05)$. 
its photosynthetic capacity. The fact that these microalgae grew exclusively under less than 200 $\mu \mathrm{mol} \mathrm{m} \mathrm{m}^{-2} \mathrm{~s}^{-1}$ of light appeared inconsistent with its normal habitat in Antarctica, where light is a limiting factor during winter and early spring, but abundant in summer. The PPF at coastal Antarctic areas varies between $0.1 \mu \mathrm{mol} \mathrm{m} \mathrm{m}^{-2} \mathrm{~s}^{-1}$ in winter and 2,000 $\mu \mathrm{mol} \mathrm{m} \mathrm{m}^{-2} \mathrm{~s}^{-1}$ in the summer (Pannewitz et al. 2003). Further, the springsummer seasons result in a significant increase in surface UV radiation (Cordero et al. 2014). The adaptive responses of microalgae (Gomez et al. 2009) and snow microalgae to photosynthetically active radiation (PAR) at this broad range of light intensity and light quality (wavelength) as well as the limiting threshold for the production of cold-response proteins and lipids with cryoprotective potential are still poorly understood (Lyon et al. 2014). For instance, total lipid fractions of Chlamydomonas sp. analyzed by flow cytometry consisted mostly of neutral lipids, yielding $93 \%$ neutral lipids to only $7 \%$ polar lipids. These results were consistent with prior observations that levels of neutral lipids in these microalgae significantly exceeded those of polar lipids (Huang et al. 2009).

The results shown in Table 2 for fatty acid content are consistent with the lipid profile for Chlorella and Chlamydomonas previously reported by Shukla et al. (2013) and Teoh et al. (2004). The general lipid profile of our initial Chlamydomonas sp. (DPA-02) sample used for the experiment showed a high content of SAFAs (58\%), while MUFAs were about $40 \%$, and PUFAs around $2 \%$. Recent studies demonstrated that Chlamydomonas sp. showed significant dependence on light intensity for their FA profiles and produced less PUFAs when grown under lower light intensities than at higher light intensities (Poerschmann et al. 2004), which was consistent with our results under low light intensity. Spijkerman et al. (2012) reported that similar strains grown at low nitrogen $(<0.005$ mg $\mathrm{N} \mathrm{l}^{-1}$ ) and high light intensity (380-400 $\mu \mathrm{mol}$ photons $\mathrm{m}^{-2} \mathrm{~s}^{-1}$ ) showed high levels of C18:1n-9. Meanwhile, Bidigare et al. (1993) further reported that red snow algal communities in Antarctica had a higher content of unsaturated FAs (88\%) than green snow microalgae (72\%).
Fatty acids play an important role in the energy metabolism and in the general physiology of microalgae. They may be present as lipid droplets or linked to carbohydrates as glycolipids and represent structural and integral parts of biological membranes, for example, as phospholipids and glycolipids (Thompson 1996). The relative composition of FAs differs between microalgae strains and may also strongly depend on environmental stress factors such as temperature, nutrient availability, and solar radiation (Roessler, 1990). Low-temperatureadapted organisms usually contain a higher ratio of polyunsaturated FAs (PUFAs) to saturated FAs (SFAs). PUFAs are especially incorporated into the lipids of membranes to maintain its fluidity, flexibility, and functionality under cold conditions. In addition, the nutritional regime will change the FA composition of algae (Spijkerman et al. 2011; Piepho et al. 2010), having in most cases a higher total FA content in nutrient-limited cultures (Rodolfi et al. 2009).

\section{Fatty acid profile after \\ exposure to dark period}

Focusing on the more abundant components present in the lipid profiles of Chlamydomonas sp. after exposure to a one-month dark period, several observations could be made (Table 4). In the control sample, the FA present in greater proportion was by far palmitic acid (16:0), with a relative abundance of approximately $39 \%$. This was consistent with previous findings in the red microalga Porphyridium cruentum (Durmaz et al. 2007). However, the proportion of 16:0 FA was reduced almost by half after exposure to the dark period, and the predominant component became the $18: 3 \omega 3 c$ FA with a relative concentration above $40 \%$. The 16:3 $\omega 3 \mathrm{c}$ was consistently around $13 \%$ to $14 \%$, with the exception of the cell culture kept at $0{ }^{\circ} \mathrm{C}$, which did not show a measurable amount. The other main component among PUFAs was 18:2 $\omega 6 \mathrm{c}$, which appeared in the initial sample with a relative concentration of around $4 \%$ and increased to around $13 \%$ in all the treatments. It has been already established that low temperatures generally increase the content of PUFAs because desaturase activity quickly increases 
Table 4. Main FA content among samples of microalga subject to a dark period of one month at different temperatures.

\begin{tabular}{|c|c|c|c|c|c|c|}
\hline & SAFA & $\%$ content & MUFA & $\%$ content & PUFA & $\%$ content \\
\hline \multirow[t]{4}{*}{ Initial Sample } & $\mathrm{C} 12: 0$ & 1.75 & C16:1 $\omega 7 \mathrm{c}$ alcohol & 2.94 & $C 16: 3 \omega 6 c$ & 4.46 \\
\hline & $\mathrm{C} 16: 0$ & 38.58 & $\mathrm{C} 16: 1 \omega 7 \mathrm{c}$ & 5.55 & $\mathrm{C} 18: 2 \omega 6 \mathrm{c}$ & 4.04 \\
\hline & C17:0 cyclo $\omega 7 \mathrm{c}$ & 2.15 & $\mathrm{C} 18: 1 \omega 9 \mathrm{c}$ & 9.22 & & \\
\hline & C18:0 & 5.46 & $\mathrm{C} 18: 1 \omega 8 \mathrm{c}$ & 5.09 & & \\
\hline \multirow[t]{3}{*}{ Culture at $0^{\circ} \mathrm{C}$} & C16:0 anteiso & 2.56 & $\mathrm{C} 16: 1 \omega 3 \mathrm{c}$ & 13.73 & $C 16: 3 \omega 6 c$ & 1.47 \\
\hline & $\mathrm{C} 16: 0$ & 16.52 & & & $\mathrm{C} 18: 3 \omega 3 \mathrm{c}$ & 42.75 \\
\hline & C17:0 10-methyl & 3.88 & & & $\mathrm{C} 18: 2 \omega 6 \mathrm{c}$ & 12.69 \\
\hline \multirow[t]{3}{*}{ Culture at $4^{\circ} \mathrm{C}$} & C16:0 anteiso & 2.62 & $\mathrm{C} 18: 1 \omega 3 \mathrm{c}$ & 1.10 & $\mathrm{C} 16: 3 \omega 3 \mathrm{c}$ & 14.24 \\
\hline & $\mathrm{C} 16: 0$ & 15.46 & $\mathrm{C} 18: 1 \omega 9 \mathrm{c}$ DMA & 1.66 & $\mathrm{C} 18: 3 \omega 3 \mathrm{c}$ & 42.87 \\
\hline & C17:0 10-methyl & 3.62 & & & $\mathrm{C} 18: 2 \omega 6 \mathrm{c}$ & 12.69 \\
\hline \multirow[t]{4}{*}{ Culture at $13^{\circ} \mathrm{C}$} & C16:0 anteiso & 2.60 & & & $\mathrm{C} 16: 3 \omega 3 \mathrm{c}$ & 13.83 \\
\hline & C16:0 & 16.57 & & & $\mathrm{C} 16: 3 \omega 6 \mathrm{c}$ & 1.41 \\
\hline & C17:0 10-methyl & 3.67 & & & $\mathrm{C} 18: 3 \omega 3 \mathrm{c}$ & 43.10 \\
\hline & & & & & $\mathrm{C} 18: 2 \omega 6 \mathrm{c}$ & 13.01 \\
\hline \multirow[t]{3}{*}{ Culture at $18^{\circ} \mathrm{C}$} & C16:0 anteiso & 2.69 & & & $\mathrm{C} 16: 3 \omega 3 \mathrm{c}$ & 14.29 \\
\hline & C16:0 & 16.43 & & & $\mathrm{C} 18: 3 \omega 3 \mathrm{c}$ & 44.60 \\
\hline & C17:0 10-methyl & 3.30 & & & $\mathrm{C} 18: 2 \omega 6 \mathrm{c}$ & 13.22 \\
\hline \multirow[t]{4}{*}{ Culture at $23^{\circ} \mathrm{C}$} & C16:0 anteiso & 2.60 & & & $\mathrm{C} 16: 3 \omega 3 \mathrm{c}$ & 13.07 \\
\hline & $\mathrm{C} 16: 0$ & 16.01 & & & $\mathrm{C} 16: 3 \omega 6 \mathrm{c}$ & 1.48 \\
\hline & C17:0 10-methyl & 3.85 & & & $\mathrm{C} 18: 3 \omega 3 \mathrm{c}$ & 44.00 \\
\hline & & & & & $\mathrm{C} 18: 2 \omega 6 \mathrm{c}$ & 13.27 \\
\hline
\end{tabular}

in direct proportion to temperature (Hochachka et al. 2002). However, the treatments exposed to a period lacking light exhibited significant increase in PUFAs independently of the treatment temperature.

Snow microalgae adjust their physiological mechanisms in order to maintain growth, reproduction and metabolic activity despite environmental conditions capable of shutting down cellular processes in most mesophilic organisms. Therefore, metabolites and compounds from these highly adaptable psychrophiles may have far-reaching biotechnological applications. The increased concentration of unsaturated lipids in snow microalgae samples as a consequence of exposure to a prolonged dark period at various temperature levels clearly showed the possibility of designing environmental conditions for the production of PUFAs. These results open several possibilities for bioprocess/industrial applications for these snow microalgae, including the biofermentation for desired chemical products. 


\section{Cell culture response to salinity}

Assessing cell growth under different salinities showed that the highest average specific growth rate $(\mu)$ observed of 0.9 day $^{-1}$ corresponded to the culture medium with zero salinity. As shown in Fig. 3, cell growth inhibition was proportional to the magnitude of salinity. The cell culture density decreased by almost $50 \%$ at the high salinity level of 16 UPS even though the culture remained viable during the treatment period.

Overall, the cultures showed greater variability in growth after reaching peak performance, i.e., during the decay phase. Notably, at the final stage of the growth curve, the microalga remained viable, but with a decreasing growth rate. For instance, the growth rate at zero salinity decreased by half, from 0.9 to 0.46 day $^{-1}$, from day 21 to day 42 , respectively. Similar trends were observed in all the treatments, suggesting that even if conditions were sub-optimal, the microalga remained likely prone to adaptive changes, allowing its survival.

\section{Substrate-induced cryo-injury}

A potentially significant factor present in a snow microalgae's habitat is physical substrate. The microalga in this study is found normally at about $2.54 \mathrm{~cm}$ below the snow surface during its summer "bloom", suggesting the importance of the physical substrate or matrix effect on the growth of the microalga (Cid-Agüero et al. 2012).

Fig. 4 shows an indirect mortality trend measured by MTS which roughly approached the exclusion dye's results. The overall influences of freezing and particle presence by the methods employed allowed the confirmation of the occurrence of cryo-damage, been it more evident in when sands or silt are used as a substrate. We found no references in the literature related to this effect, though it appeared consistent with our working model for low-temperature adaptation by snow microalgae, originated by Clarke et al. (2013), where intracellular vitrification constituted the alleged prevailing mechanism preventing the occurrence of lethal intracellular freezing, allowing cell viability upon freezing for preservation.

During slow cooling in the presence of extracellular ice as the substrate, resembling the natural environment; free-living microbial cells are subject to dehydration as freezeconcentration of the external aqueous medium withdraws water from the cell. This is followed by a significant increase in intracellular viscosity and, at temperatures above $-22^{\circ} \mathrm{C}$, cell contents undergo a colloid glass transition, that is, intracellular vitrification without any internal freezing (Zhou et al. 2009). The vitrification process is important to the survival of cells at low temperature because the glass transition does not involve the change in density that accompanies nucleation and freezing. A cell that freezes becomes subject to significant mechanical stresses, which are frequently lethal. Cells that vitrify are also behaving effectively as a solid, but retain their internal structure and integrity, which is the key factor in allowing them back to regular cell-cycle, movement and metabolism once an increase of the surrounding temperature occurs (Morowitz, 1978).

MTS assay used a tetrazolium compound (Owen's reagent) which is bio-reduced by cells into a colored soluble formazan. When using this method in the presence of particles which may adhere to measurable products, the methodology is immediately ruled out as appropriate for cell counting. Nevertheless, it is considered to be a useful tool for comparing conditions such in this study. Trypan blue differential counting was ineffective with a silt-fraction condition.

\section{CONCLUSIONS}

In conclusion, this study demonstrated the successful culturing of the Antarctic snow microalga Chlamydomonas sp. (DPA-02) after two years of being stored in a freezer at $-4{ }^{\circ} \mathrm{C}$ in continuous darkness. The study also showed the significant alteration of the microalga's lipid profile by modifying the culture's growing conditions, resulting in a significant increase in PUFA's when the culture was subjected to continuous darkness over a one-month period independently of the culture temperature. The growth rate of the microalga decreased with increase in $\mathrm{NaCl}$ concentration in the growing medium. Further, the microalga was found to be 
sensitive to the physical matrix on which it grew, showing a higher mortality rate when exposed to a low-temperature shock on a solid medium different than snow or ice.

\section{ACKNOWLEDGEMENTS}

This study was kindly funded by a research grant from the U.S. Air Force Office of Science and Research, FA9550-31-1-0055. The main author thanks Professors Sylvia Oyarzún and Mauricio Palacios for sharing their research facilities. The field assistance of the Chilean Army Antarctic division and Chilean Antarctic O'Higgins Base personnel are gratefully acknowledged.

\section{REFERENCES}

Aaronson, S. (1973). Effect of incubation temperature on the macromolecular and lipid content of the phytoflagellate Ochromonas danica. Journal of Phycology, (9), 111113.

Aristarain, A. J., \& Delmas, R. J. (2002). Snow chemistry measurements on James Ross Island (Antarctic Peninsula) showing seasalt aerosol modifications. Atmospheric Environment, 36(4), 765-772.

Arnold, R. J., Convey, P., Hughes, K. A., \& WynnWilliams, D. D. (2003). Seasonal periodicity of physical factors, inorganic nutrients and microalgae in Antarctic fellfields. Polar Biology, 26(6), 396-403.

Barrett, J. (2001). Thermal hysteresis proteins. The International Journal of Biochemistry \& Cell Biology, 33(2), 105-117.

Bayer-Giraldi, M., Jin, E., \& Wilson, P. W. (2014). Characterization of Ice Binding Proteins from Sea Ice Algae. In Plant Cold Acclimation (pp. 241-253). New York: Springer.

Becker, S., Graeve, M., \& Bischof, K. (2010). Photosynthesis and lipid composition of the Antarctic endemic rhodophyte Palmaria decipiens: efects of changing light and temperature levels. Polar Biology, 33, 945955.

Benson, E. E. (2008). Cryopreservation of Phytodiversity: A Critical Appraisal of Theory \& Practice, Critical Reviews in
Plant Sciences, 27(3), 141-219.

Bidigare, R. R., Ondrusek, M. E., Kennicutt, M. C., Iturriaga, R., Harvey, H. R., Hoham, R. W., \& Macko, S. A. al. (1993). Evidence for a photoprotective for secondary carotenoids of Snow algae. Journal of Phycology, 29, 427-43.

Boussiba, S., Vonshak, A., Cohen, Z., Avissar, Y., \& Richmond, A. (1987). Lipid and biomass production by the halotolerant microalga Nannochloropsissalina. Biomass, 12, 3747.

Capasso, J. M., Cossío, B. R., Berl, T., Rivard, C. J., \& Jiménez, C. (2003). A colorimetric assay for determination of cell viability in algal cultures. Biomolecular engineering, 20(4), 133-138.

Cid-Agüero, P., Cárdenas, P., \& Moreno, J. (2012). Response of Antarctic snow microalgae culture to effects of temperature, irradiance and supporting media. Anales Instituto Patagonia, 40(1), 153-156.

Clarke, A., Morris, G. J., Fonseca, F., Murray, B. J., Acton, E., \& Price, H. C. (2013). A low temperature limit for life on earth. PLoS ONE, 8(6) e66207.

Cordero, R. R., Damiani, A., Ferrer, J., Jorquera, J., Tobar, M., Labbe, F., Carrasco, J., \& Laroze, D. (2014). UV Irradiance and Albedo at Union Glacier Camp (Antarctica): A Case Study. PLoS ONE, 9(3), e90705.

Cronan, J. E. Jr., Gennis, R. B., \& Maloy, S. R. (1987). Cytoplasmic membrane, p. 3155. In F. C. Neidhardt, J. L. Ingraham, K. B. Low, B. Magasanik, M. Schaechter, and H. E. Umbarger (Ed.), Escherichia coli and Salmonella: cellular and molecular biology. Washington: American Society for Microbiology.

Cruces, E., Huovinen, P., \& Gómez, I. (2013). Interactive effects of $\mathrm{UV}$ radiation and enhanced temperature on photosynthesis, phlorotannin induction and antioxidant activities of two sub-Antarctic brown algae. Marine Biology, 160(1), 1-13.

Debenedetti, P. G., \& Stillinger, F.H. (1996). Review article Supercooled liquids and the glass transition. Nature, 410, 259-267.

Durmaz, Y., Monteiro, M., Bandarra, N., 
Gökpinar, Ş., \& Işik, O. (2007). The effect of low temperature on fatty acid composition and tocopherols of the red microalga, Porphyridiumcruentum. Journal of Applied Phycology, 19, 223-227.

Fong, N. J. C., Burgess, M. L., Barrow, K. D., \& Glenn, D. R. (2001). Carotenoid accumulation in the psychrotrophic bacterium Arthrobacteragilis in response to thermal and salt stress. Applied Microbiology Biotechnology, 56, 750-756.

Gómez, I., Wulff, A., Roleda, M. Y., Huovinen, P., Karsten, U., Quartino, M. L., Dunton, K., \& Wiencke, C. (2009). Light and temperature demands of marine benthic microalgae and seaweeds in polar regions. Botanica Marina, 52(6), 593-608.

Guckert, J. B., \& Cooksey, K. E. (1990). Triglyceride accumulation and fatty acid profile changes in Chlorella (Chlorophyta) during high $\mathrm{pH}$ induced cell cycle inhibition. Journal of Phycology, 26, 72-79.

Gunderson, A. R., Armstrong, E. J., \& Stillman, J. H. (2016). Multiple stressors in a changing world: the need for an improved perspective on physiological responses to the dynamic marine environment. Annual Review of Marine Science, 8, 357-378.

Guschina, I. A., \& Harwood, J. L. (2006). Lipids and lipid metabolism in eukaryotic algae. Progress in Lipid Research, 45, 160-186.

Hochachka, P. W., \& Somero, G. N. (2002). Biochemical Adaptation - Mechanism and Process in Physiological Evolution, Oxford: Oxford University Press.

Hondzo, M., \& Wüest, A. (2008). Do microscopic organisms feel turbulent flows? Environmental Science \& Technology, 43(3), 764-768.

$\mathrm{Hu}$, Q., Sommerfeld, M., Jarvis. E., Ghirardi, M., Posewitz, M., Seibert, M., \& Darzins, A. (2008). Microalgal triacylglycerols as feedstocks for biofuel production: perspectives and advances. Plant Journal, 54, 621-639.

Huang, G. H., Chen, G., \& Chen, F. (2009). Rapid screening method for lipid production in alga based on Nile red fluorescence. Biomass and Bioenergy, 33, 1386-1392.
Kawecka, B., \& Drake (1978). Biology and Ecology of Snow Algae. Acta Hidrobiológica, 20, 111-116.

Leya, T., Rahn, A., Lutz, C., \& Remias, D. (2009). Response of arctic snow and permafrost algae to high light and nitrogen stress by changes in pigment composition and applied aspects for biotechnology. FEMS Microbiology Ecology, 67, 432-443.

Lukes, M., Prochazkova, L., Smith, V., Nedbalova, L., \& Kaftan, D. (2014). Temperature dependence of photosynthesis and thylakoid lipid composition in the red snow alga Chlamydomonas cf. nivalis (Chorophyceae). FEMS Microbiology Ecology, 1-14.

Lyon, B. R., \& Mock, T. (2014). Polar Microalgae: New Approaches towards Understanding Adaptations to an Extreme and Changing Environment. Biology, 3, 56-80.

Mader, H. M. (1992). Observations of the watervein system in polycrystalline ice. Journal of Glaciology, 38(130), 333-347.

Mader, H. M., Pettitt, M.E., Wadham, J. L, Wolff, E. W., \& Parkes, R. J. (2006). Subsurface ice as a microbial habitat. Geology, 34(3), 169-172.

Malits, A., Peters, F., Bayer-Giraldi, M., Marrasé, C., Zoppini, A., Guadayol, O., \& Alcaraz, M. (2004). Effects of small-scale turbulence on bacteria: a matter of size. Microbial Ecology, 48(3), 287-299.

Mazur, P. (1970). Cryobiology: the freezing of biological systems. Science, 168(3934), 939-949.

Mazur, P. (2004). Principles of Cryobiology. In: Fuller NLBJ, Benson EE, editors, Life in the Frozen State (pp. 3-65). Boca Raton: CRC Press.

Mazur, P. (2010). A biologist's view of the relevance of thermodynamics and physical chemistry to cryobiology, Cryobiology, 60, 4-10.

Morowitz, H. J. (1978). Foundations of bioenergetics (pp. 344). New York: Academic Press.

Pannewitz, S., Schlensog, M., Green, T.G.A., Sancho, L. G., \& Schoeter, B. (2003). Are lichens active under snow in continental Antarctica? Oecologia, 135, 30-38. 
Pearce, D. A. (2008). Climate change and the microbiology of the Antarctic Peninsula region. Science Progress, 91(2), 203-217.

Piepho, M., Martin-Creuzburg, D., \& Wacker, A. (2010). Simultaneous effects of light intensity and phosphorus supply on the sterol content of phytoplankton. PLoSONE 5, e15828.

Piorreck, M., Baasch, K. H., \& Pohl, P. (1984). Biomass production, total protein, chlorophylls, lipids and fatty acids of freshwater green and blue-green algae under different nitrogen regimes. Phytochemistry, 23, 207-216.

Poerschmann, J., Spijkerman, E., \& Langer, U. (2004). Fatty acid patterns in Chlamydomonas sp. as a marker for nutritional regimes and temperature under extremely acidic conditions. Microbial Ecology, 48, 78-89.

Pocock, T., Vetterli, A., \& Falk, S. (2011). Evidence for phenotypic plasticity in the Antarctic extremophile Chlamydomonas raudensis Ettl. UWO 241. Journal of Experimental Botany, 62(3), 1169-1177.

Rapatz, G. L., Menz, L. J., \& Luyet, B. J. (1966). Freezing process in biological materials. In H. T. Meryman (Ed.), Cryobiology (pp. 147148). London: Academic Press.

Rezanka, T., Nedbalova, L., \& Sigler, K. (2008). Unusual medium-chain polyunsaturated fatty acids from the snow alga Chloromonas brevispina. Microbiological Research, 163, 373-379.

Rodolfi, L., Chini, G., Bassi, N., Padovani, G., Biondi, N., \& Tredici, M. R. (2009). Microalgae for oil: strain selection, induction of lipid synthesis and outdoor mass cultivation in a low-cost photobioreactor, Biotechnology Bioenergy, 102(1),100112.

Roessler, P. G. (1990). Environmental control of glycerolipid metabolism in microalgae: commercial implications and future research directions. Journal of Phycology, 26, 393399.

Shukla, S. P., Kviderova, J., Triska, J., \& Elster,
J. (2013). Chlorella mirabilis as a potential species for biomass production in lowtemperature environment. Frontier in Microbiology, 4(97), 1-12.

Spijkerman, E., Wacker, A., Weithoff, G., \& Leya, T. (2012). Elemental and fatty acid composition of snow algae in Arctic habitats. Frontier in microbiology, 3(380), 1-15.

Vishnivetskaya, T. A., Spirina, E. V., Shatilovich, A. V., Erokhina, L. G., Vorobyova, E. A., \& Gilichinsky, D. A. (2003). The resistance of viable permafrost algae to simulated environmental stresses: implications for astrobiology. International Journal of Astrobiology, 2(03), 171-177.

Vishnivetskaya, T. A., Siletzky, R., Jefferies, N., Tiedje, J. M., \& Katharius, S. (2007). Effect of low temperature and culture media on the growth and freeze-thawing tolerance of Exiguo bacterium strains. Cryobiology, 54, 234-240.

Wettlaufer, J. S. (2001). Dynamics of ice surfaces, Interface Science, 9, 115-27.

Wowk, B. (2010). Thermodynamic aspects of vitrification. Cryobiology, 60(1), 11-22.

Teoh, M. L., Chu, W. L., Marchant, H., \& Phang, S. M. (2004). Influence of culture temperature on the growth, biochemical composition and fatty acid profiles of six Antarctic microalgae, Australia. Journal of Applied Phycology, 16, 421- 430.

Thompson, G. A. (1996). Lipids and membrane function in green algae. Biochimca et Biophysica. Acta, 1302, 17-45.

Zhang, Q., Gradinger, R., Zhou Q.S. (2003). Competition within the marine microalgae over the polar dark period in the Greenland Sea of high Arctic. Acta Oceanologica Sinica, 22(2), 233-242.

Zhou, E. H., Trepat, X., Park, C. Y., Lenormand, G., Oliver, M. N., Mijailovich, S. M., Hardin, C.,... \& Fredberg, J. J. (2009). Universal behavior of the osmotically compressed cell and its analogy to the colloidal glass transition. Proceedings of the National Academy of Sciences of the United States of America, 106(26), 10632-10637. 